\title{
Faktor-Faktor Yang Mempengaruhi Minat Penggunaan Sistem E-Filing Untuk Hotel Dan Restoran Di Wilayah Perbatasan RI-RDTL
}

\author{
Scolastika Simu ${ }^{1}$, Sugeng Hariadi ${ }^{2}$ \\ ${ }^{1,2}$ Program Studi Akuntansi \\ ${ }^{1,2}$ Sekolah Tinggi Ilmu Ekonomi Malangkuçeçwara, Malang \\ Email : scolastikasimu@gmail.com ${ }^{1}$, hariadisg@yahoo.com ${ }^{2}$
}

\begin{abstract}
ABSTRAK
Tujuan dari penelitian ini yaitu untuk menganalisis apakah sosialisasi pelaporan pajak online, pengetahuan pajak,persepsi kemudahan dan pemahaman IT berpengaruh terhadap keinginan penggunaan system e-Filing untuk hotel dan restoran yang berada di wilayah perbatasan RI-RDTL. Jenis penelitian yang digunakan yaitu penelitian kuantitatif. Sampel yang digunakan sebanyak 71 yang terdiri dari 13 hotel dan 58 restoran. Metode analisis yang digunakan yaitu dengan pendekatan partial least square (PLS). Hasil dari pengujian menunjukkan bahwa sosialisasi pelaporan pajak online memiliki pengaruh positif namun tidak signifikan terhadap keinginan menggunakan sistem E-filing untuk hotel dan restoran di wilayah perbatasan RI-RDTL, Pengetahuan pajak tidak berpengaruh positif dan tidak signifikan terhadap minat penggunaan system e-filing untuk hotel dan restoran di wilayah perbatasan RI-RDTL, Persepsi kemudahan berpengaruh positif dan signifikan terhadap minat penggunaan system e-filing untuk hotel dan restoran di wilayah perbatasan RI-RDTL, Pemahaman teknologi informasi tidak memiliki pengaruh positif dan tidak signifikan terhadap minat penggunaan system e-filing untuk hotel dan restoran di wilayah perbatasan RI-RDTL.
\end{abstract}

Kata kunci: e-filing, sosialisasi, pengetahuan pajak, persepsikemudahan, pemahaman teknologi informasi

\section{ABSTRACT}

The purpose of this study is to analyze whether the socialization of online tax reporting, tax knowledge, perception of ease and understanding of information technology affect the interest in the use of e-filing system for hotels and restaurants located in the border area of RI-RDTL, the type of research used is quantitative research. The sample used 71 consisting of 13 hotels and 58 restaurants. The analysis method used is with partial least square (PLS) approach.The results of the test showed that the socialization of online tax reporting had a positive but insignificant effect on the interest in the use of efiling system for hotels and restaurants in the border region of RI-RDTL, Tax knowledge has no positive and insignificant effect on the interest in the use of e-filing system for hotels and restaurants in the border region of RI-RDTL, Understanding information technology has no positive and insignificant influence on the interest in the use of e-filing systems for hotels and restaurants in the border region of RI-RDTL.

Keywords: e-filing, socialization, tax knowledge, perception of ease, understanding of information technology 


\section{PENDAHULUAN}

Salah satu penghasilan atau pendapatan terbesar suatu negara dalam memenuhi pengeluaran pemerintahan yaitu dari adanya pembayaran pajak oleh masyarakat. Kemajuan teknologi membuat pekerjaan semakin mudah, dengan adanya kemajuan teknologi ini direktorat jendral pajak membuat suatu inovasi baru dalam meningkatkan penerimaan kas negara. Dalam hal pelaporan pajak, pihak direktorat jendral pajak berupaya melakukan perbaikan aspek IT (information technology) dan komunikasi yaitu dengan adanya perubahan penerapan sistem pengisian SPT dari manual menjadi pengisian SPT melalui internet atau yang lebih dikenal dengan (electronic filing) atau E-Filing. E-filing merupakan sistem pelaporan pajak online dengan mengisi SPT secara online dan dapat dilakukan kapan saja dan dimana saja. Adanya sistem E-filing ini dapat membantu dan memudahkan para wajib pajak dalam menghitung, mengisi dan melaporkan SPT tahunannya tanpa harus mengunjungi KPP.

Di wilayah perbatasan RI-RDTL tepatnya di kabupaten Belu, wajib pajak masih banyak yang belum memahami mengenai layanan sistem E-filing.masih banyak wajib pajak yang belum menerapkan layanan sistem e-filing tersebut. Wajib pajak di wilayah perbatasan ini masih lebih memilih melaporkan SPT tahunannya secara manual ke kantor pajak atau melalui kantor pos. Penyebab sedikitnya minat wajib pajak dalam penggunaan sistem e-filing dikarenakan sistem e-filing masih sangat baru sehingga masih banyak kekurangan dan juga pemahaman yang ada pada wajib pajak yang menyebabkan wajib pajak lebih memilih melaporkan pajaknya langsung ke kantor pajak atau melalui kantor pos.

Beberapa penelitian sebelumnya dilakukan oleh (Kurniawati, 2018) bahwa persepsi kegunaan, persepsi kemudahan, kompleksitas pengguna, kesukarelaan, pengalaman, keamanan dan kerahasiaan memiliki pengaruh positif dan signifikan terhadap minat perilaku dalam menggunakan e-filing, (Pu’o, Sondakh, \& Budiarso, 2018) mengatahkan bahwa persepsi kegunaan dan kemudahan, keamanan dan kerahasiaan, kesiapan teknologi informasi memiliki pengaruh positif terhadap minat wajib pajak dalam penggunaan e-filing, dan kerumitan berpengaruh negatif terhadap minat wajib pajak dalam menggunakan e-filing (Lie \& Sadjiarto, 2013) mengatakan bahwa persepsi kegunaan,persepsi kemudahan dan faktor sosial berpengaruh terhadap minat wajib pajak dalam menggunakan e-filing, (Wibisono \& Toly, 2014) mengatakan 
bahwa dalam pelaporan pajak dengan e-filing, setiap orang harus paham menggunakan teknologi terlebih dahulu untuk dapat mengaplikasikan e-filing sebagai sarana pelaporan pajaknya. Hasil penelitiannya menunjukkan adanya pengaruh keamanan dan kerahasiaan, kesiapan teknologi informasi, persepsi kegunaan dan persepsi kemudahan terhadap minat wajib pajak menggunakan e-filing di Surabaya. Sedangkan menurut (Daryatno, 2017) mengatakan bahwa persepsi kemudahan dan pengetahuan umum perpajakan tidak mempunyai pengaruh terhadap penggunaan e-filing. (Amalia, 2020) penelitian ini menunjukkan bahwa penerapan e-sistem, sosialisasi dan pengetahuan perpajakan memiliki pengaruh yang positif terhadap kepatuhan wajib pajak orang pribadi, dan sanksi perpajakan tidak memiliki pengaruh positif terhadap kepatuhan wajib pajak orang pribadi. (Fadhila \& Diansyah, 2018) Hasil penelitian ini menunjukkan bahwa sosialisasi perpajakan tidak memiliki pengaruh signifikan terhadap kepuasan penggunaan sistem e-filing, kualitas sistem perpajakan dan sosialisasi perpajakan tidak memiliki pengaruh yang signifikan terhadap kepuasan penggunaan sistem e-filing.

Berdasarkan uraian tersebut, maka perumusan masalah yang akan dibahas yaitu : Apakah sosialisasi pelaporan pajak online,pengetahuan pajak, persepsi kemudahan dan pemahaman teknologi dan informasi berpengaruh positif terhadap minat penggunaan sistem e-filing untuk hotel dan restoran di wilayah perbatasan RI-RDTL?. Tujuan dalam penelitian ini yaitu untuk menganalisis pengaruh sosialisasi pelaporan pajak online, pengetahuan pajak, persepsi kemudahan dan pemahaman teknologi dan informasi terhadap minat penggunaan sistem e-filing untuk hotel dan restoran di wilayah perbatasan RI-RDTL.

\section{Tinjauan Pustaka}

\section{Pajak}

Pengertian pajak dari berbagai sudut pandang dan pemikiran yang berbeda, memberikan Batasan pengertian mengenai pajak. Definisi pajak merupakan sarana pembayaran kewajiban oleh masyarakat kepada pemerintah dalam memenuhi pemasukkan kas negara untuk pembiayaan pengeluaran pemerintahan dan juga dapat digunakan sebagai pembangunan infrastruktur dalam negeri (Soemitro, 1992). Adapun menurut PJA adriani yang mengatakan pajak merupakan iuran yang harus dibayarkan 
masyarakat kepada negara yang bersifat memaksa untuk dibayarkan dan tidak mengharapkan balasan apapun sesuai dengan undang-undang yang berlaku.

Dengan demikian dapat disimpukan bahwa pajak merupakan pendapatan terbesar pemerintah dari iuran yang diberikan masyarakat untuk memenuhi pengeluaran pemerintahan.

\section{E-Filing}

E-filing adalah sistem pelaporan SPT menggunakan sarana internet, yang dibuat oleh DJP untuk memberikan kemudahan bagi wajib pajak dalam melaporkan pajaknya dengan lebih mudah dan cepat. Sistem E-filing ini dapat membantu wajib pajak dalam melaporkan pajaknya dimana saja dan kapan saja (Daryatno, 2017).

\section{Minat Wajib Pajak}

Minat merupakan ketertarikan seseorang akan sesuatu hal dibandingkan dengan hal lainnya, yang berarti keinginan seseorang untuk memiliki sesuatu sesuai dengan keinginannya. Minat wajib pajak adalah keinginan dari diri wajib pajak untuk menggunakan sistem pelaporan pajak secara online dengan menggunakan e-filing atau mengunjungi langsung KPP (offline) (Kurniawati, 2018).

\section{Penerimaan E-Filing Oleh Wajib Pajak}

Pembaruan yang dilakukan oleh DJP tidak hanya pada peraturan pajaknya saja namun pelayanan kepada masyarakat juga mendapat pembaharuan pada sistem pelaporan pajaknya yaitu dengan adanya layanan pelaporan pajak menggunakan efiling. Dengan perkembangan teknologi yang ada, DJP terus melakukan inovasiinovasi baru yang dapat memudahkan wajib pajak dalam menjalankan kewajiban perpajakannya.

\section{METODE PENELITIAN}

Jenis penelitian yaitu penelitian kuantitatif kausal, dengan menggunakan data primer dan metode angket. Variabel yang digunakan yaitu sosialisasi pelaporan pajak, pengetahuan pajak, persepsi kemudahan dan IT, minat wajib pajak hotel dan restoran dalam menggunakan sistem e-filing. Populasi dari penelitian ini adalah wajib pajak 
untuk hotel dan restoran yang berada di wilayah perbatasan RI-RDTL. Dalam menentukan sampel menggunakan voluntary sampling(sampling sukarela). Terdapat 71 perusahaan yang terdiri dari 13 hotel dan 58 restorant. Analisis data yang digunakan dalam penelitian ini adalah pendekatan partial least square (PLS).

\section{HASIL DAN PEMBAHASAN}

Data responden yang digunakan merupakan hasil penyebaran kuesioner kepada wajib pajak hotel dan restoran yang berada di kabupaten belu perbatasan RI-RDTL. Hasil dari statistic deskriptif tampak sebagai berikut :

Tabel 1. Rangkuman Statistik Deskriptif

\begin{tabular}{|c|c|c|c|c|c|c|c|}
\hline Variabel & $\mathrm{N}$ & MIN & MAX & MO & $\mathrm{ME}$ & $\mathrm{M}$ & SD \\
\hline $\begin{array}{l}\text { Sosialisasi pelaporan pajak } \\
\text { online }\end{array}$ & 32 & 7 & 17 & 12 & 13 & 12,78 & 2,66 \\
\hline Pengetahuan pajak & 32 & 6 & 15 & 12 & 12 & 12 & 1,98 \\
\hline Persepsi kemudahan & 32 & 16 & 40 & 24 & 24 & 24,78 & 6,25 \\
\hline $\begin{array}{l}\text { Pemahaman teknologi in- } \\
\text { formasi }\end{array}$ & 32 & 4 & 10 & 8 & 8 & 7,84 & 1,52 \\
\hline Minat penggunaane-filing & 32 & 10 & 30 & 18 & 18 & 18 & 5,133 \\
\hline
\end{tabular}

1. Menilai model pengukuran

Dalam teknik analisis dengan menggunakan program smartPLS dalam menilai model pengukuran terdapat dua hal penting yang harus dilakukan yaitu menguji validitas dan juga menguji realibilitas. Untuk menguji validitas dengan menggunakan convergent validity yaitu dinilai berdasarkan indikator-indikator yang nilainya dibawah 0,70 harus dieliminasi atau dihapus.

Tabel 2. Loading Factor (model pengukuran)

\begin{tabular}{|c|c|c|}
\hline Indikator & Sebelum penghapusan & Modifikasi \\
\hline \multicolumn{3}{|c|}{ Sosialisasi pelaporan pajak online } \\
\hline SP 1 & 0,119 & \\
\hline SP 2 & 0,901 & 0,903 \\
\hline SP 3 & 0,813 & 0,824 \\
\hline SP 4 & 0,880 & 0,878 \\
\hline \multicolumn{3}{|c|}{ Pengetahuan Pajak } \\
\hline PP 1 & 0,935 & 1.000 \\
\hline PP 2 & 0,616 & \\
\hline PP 3 & 0,221 & \\
\hline
\end{tabular}




\begin{tabular}{lcc}
\hline Persepsi Kemudahan & & \\
\hline PK 1 & 0,901 & 0,901 \\
\hline PK 2 & 0,960 & 0,960 \\
\hline PK 3 & 0,952 & 0,952 \\
\hline PK 4 & 0,933 & 0,933 \\
\hline PK 5 & 0,879 & 0,879 \\
\hline PK 6 & 0,875 & 0,875 \\
\hline PK 7 & 0,867 & 0,867 \\
\hline PK 8 & 0,899 & 0,899 \\
\hline Pemahaman TeknologiInformasi & \\
\hline PTI 1 & 0,933 & 0,933 \\
\hline PTI 2 & 0,972 & 0,972 \\
\hline Minat Menggunakan E-Filing & \\
\hline MME 1 & 0,932 & 0,933 \\
\hline MME 2 & 0,948 & 0,948 \\
\hline MME 3 & 0,957 & 0,957 \\
\hline MME 4 & 0,939 & 0,939 \\
\hline MME 5 & 0,941 & 0,941 \\
\hline MME 6 & 0,752 & 0,751 \\
\hline
\end{tabular}

Dari tabel 2 menunjukkan masih adanya nilai pengukuran yang dibawah standar yang sebesar 0,70 yang artinya bahwa masih ada indikator dibawah 0,70 yang harus di hapus dari loading factor tersebut. Diperlihatkan dari kolom modifikasi tersebut sudah tidak memiliki indikator yang bernilai dibawah 0,70. Yang berarti indikator dibawah 0,70 sudah di hapus.

\section{Discriminant validity}

Validitas diskriminan bertujuan untuk memastikan bahwa setiap konsep dari masing-masing variabel laten berbeda dengan lainnya. Validitas diskriminan dikatakan baik jika korelasi antara variabel satu dengan variabel lainnya tidak lebih besar dari korelasi variabel itu sendiri.

Tabel 3. Nilai Discriminant Validity(cross loading)

\begin{tabular}{llllll}
\hline & X1 $(\mathrm{SP})$ & X2 $(\mathrm{PP})$ & X3 $(\mathrm{PK})$ & X4 (PTI) & Y (MME) \\
\hline SP 2 & 0,903 & $-0,042$ & 0,295 & $-0,234$ & 0,365 \\
\hline SP 3 & 0,824 & 0,005 & 0,248 & $-0,223$ & 0,207 \\
\hline SP 4 & 0,878 & $-0,017$ & 0,227 & $-0,044$ & 0,391 \\
\hline PP 1 & $-0,025$ & 1,000 & 0,292 & 0,391 & 0,199 \\
\hline PK 1 & 0,264 & 0,150 & 0,901 & 0,289 & 0,817 \\
\hline PK 2 & 0,220 & 0,326 & 0,960 & 0,228 & 0,753 \\
\hline PK 3 & 0,303 & 0,255 & 0,952 & 0,316 & 0,787 \\
\hline PK 4 & 0,311 & 0,278 & 0,933 & 0,363 & 0,768 \\
\hline
\end{tabular}




\begin{tabular}{llllll}
\hline PK 5 & 0,237 & 0,427 & 0,879 & 0,235 & 0,689 \\
\hline PK 6 & 0,249 & 0,411 & 0,875 & 0,387 & 0,730 \\
\hline PK 7 & 0,157 & 0,180 & 0,867 & 0,148 & 0,727 \\
\hline PK 8 & 0,378 & 0,132 & 0,899 & 0,268 & 0,805 \\
\hline PTI 1 & $-0,188$ & 0,386 & 0,301 & 0,933 & 0,126 \\
\hline PTI 2 & $-0,156$ & 0,367 & 0,291 & 0,972 & 0,194 \\
\hline MME 1 & 0,348 & 0,131 & 0.823 & 0,160 & 0,933 \\
\hline MME 2 & 0,320 & 0,223 & 0,820 & 0.196 & 0,948 \\
\hline MME 3 & 0,322 & 0,180 & 0,795 & 0,195 & 0,957 \\
\hline MME 4 & 0,359 & 0,116 & 0,724 & 0,190 & 0,939 \\
\hline MME 5 & 0,422 & 0,187 & 0,769 & 0,200 & 0,941 \\
\hline SME 6 & 0,378 & 0,263 & 0,646 & $-0,003$ & 0,751
\end{tabular}

Sumber : data dari smartPLS

Dalam tabel 3. Memperlihatkan indikator dari masing- masing variabel tersebut memiliki hubungan korelasi antara variabel dengan indikatornya masih lebih besar dibandingkan dengan korelasi antara indikator itu dengan variabel lainnya.

\section{Evaluasi Reability Dan (AVE)}

Dalam uji validitas dan juga realibilitas terdapat model pengujian komposit realibilitas dan juga menguji rata-rata varian diekstrak (AVE) yang bertujuan untuk mengetahui konsep atau konstruk tersebut sudah memiliki realibilitas tinggi. Dilihat dalam tabel 4 yang menunjukkan variabel variabel laten tersebut sudah memenuhi standar realibilitas karena nilai tersebut sudah melebihi untuk reliability $>70 \%$ dan AVE $>50 \%$.

Tabel 4.Komposit reliabilitas dan rata-rata varian diekstrak (AVE)

\begin{tabular}{lcc}
\hline & Reliabilitas komposit & $\begin{array}{c}\text { Rata-rata variandiekstrak } \\
(\mathrm{AVE})\end{array}$ \\
\hline $\mathrm{X} 1(\mathrm{SP})$ & 0,902 & 0,755 \\
\hline $\mathrm{X} 2(\mathrm{PP})$ & 1,000 & 1,000 \\
\hline $\mathrm{X} 3(\mathrm{PK})$ & 0,974 & 0,826 \\
\hline $\mathrm{X} 4(\mathrm{PTI})$ & 0,951 & 0,907 \\
\hline $\mathrm{X} 5(\mathrm{MME})$ & 0,968 & 0,836 \\
\hline
\end{tabular}

\section{Uji model Struktural (inner model)}

Uji model struktural ini guna untuk mengetahui hubungan antara variabel independent dan dependen, untuk melihat juga apakah adanya nilai yang bersifat positif dan signifikansi dan mengetauhi nilai $R$-square dari variabel dependennya. Model 
struktural dievaluasi dengan menunjukkan nilai r-square koefisien jalur, t-statistik, predictive relevance dan model fit.

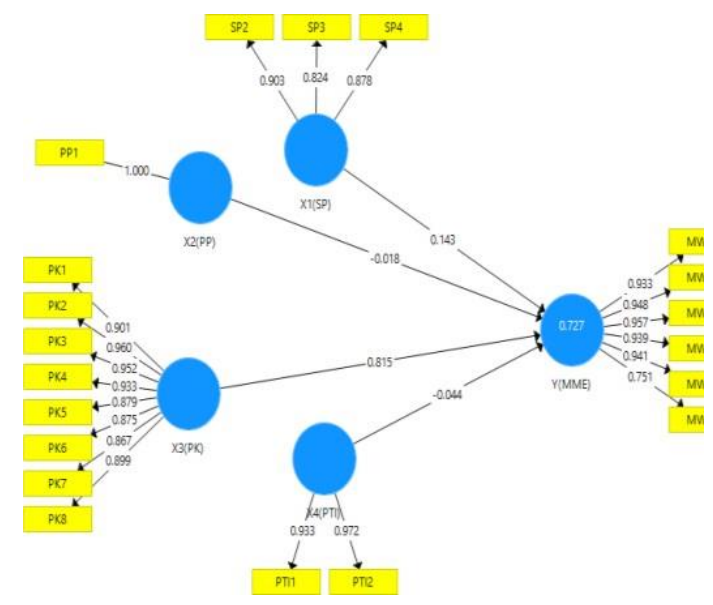

Gambar 1: Model struktural

Tabel 5. Nilai R-Square

\begin{tabular}{cl}
\hline Variabel Y (intetion to apply) & R-square \\
\hline Y (MME) & 0,727 \\
\hline
\end{tabular}

Sumber : pengolahan data dengan smartPLS, 2021

Dalam tabel 5. Nilai R-square menunjukkan pengaruh yang diberikan variabel independen terhadap variabel dependen. Yaitu pengaruh variabel sosialisasi pelaporan pajak online (X1), variabel pengetahuan pajak (X2), variabel persepsi kemudahan (X3) variabel pemahaman teknologi informasi (X4)secara simultan terhadap variabel minat penggunaan e-filing (Y) sebesar 73\% dengan 27\% dipengaruhi oleh variabel lain yang tidak diteliti dalam penelitian ini.

\section{Pengujian Hipotesis}

Pengujian ini bertujuan untuk menguji apakah sosialisasi layanan pelaporan pajak online, pengetahuan pajak, pemahaman kemudahan dan persepsi teknologi informasi memiliki pengaruh positif terhadap keinginan penggunaan sistem e-filing untuk hotel dan restoran yang berada di wilayah perbatasan RI-RDTL. Dari pengujian menggunakan software smart PLS menunjukkan bahwa path coefficient-nya yang akan menjadi dasar dalam menentukan hasil dari hipotesis. 
Tabel 6. Path coefficients

\begin{tabular}{lllll}
\hline & $\begin{array}{l}\text { Sampel } \\
\text { asli }\end{array}$ & $\begin{array}{l}\text { Rata-rata } \\
\text { sampel } \\
(\mathrm{M})\end{array}$ & $\begin{array}{l}\text { Standar } \\
\text { deviasi } \\
\text { (STDEV) }\end{array}$ & $\begin{array}{l}\text { T-statistik } \\
\text { (O/STDEV) }\end{array}$ \\
\hline X1(SP)->Y(MME) & 0,143 & 0,166 & 0,138 & 1,034 \\
\hline X2(PP)->Y(MME) & $-0,018$ & $-0,026$ & 0,119 & 0,156 \\
\hline X3(PK)->Y(MME) & 0,815 & 0,778 & 0,127 & 6,409 \\
\hline X4(PTI)->Y(MME) & $-0,044$ & $-0,043$ & 0,098 & 0,452 \\
\hline
\end{tabular}

\section{a. Pengujian hipotesis I}

Hasil pengujian hipotesis menunjukkan bahwa pengaruh $\mathrm{X} 1$ terhadap $\mathrm{Y}$ dengan sampel aslinya sejumlah 0,143 dan nilai t-statistiknya sejumlah 1,034. Perbandingan nilai t tabel $(1,96)$, maka dapat disimpulkan sosialisasi layanan pelaporan pajak online berpengaruh positif (tidak signifikan) terhadap minat penggunaan sstem e-filing. Sesuai dengan hipotesis pertama "XI berpengaruh positif terhadap Y". Maka pengujian hipotesis pertama dapat diterima.

Hal tersebut diatas bertentangan dengan penelitian yang dilakukan (Nur Anisa Putri, 2018) menunjukkan tidak adanya signifikansi antara pemasyarakatan perpajakan dengan kesenangan dalam menggunakan e-filing. Tetapi sama dengan penelitian (Amalia, 2020) mengatakan bahwa sosialisasi pajak berpengaruh positif terhadap kepatuhan pajak. Dari hasil analisis deskriptif yang didapat bahwa ada deviasi sejumlah 2,66 dari nilai M sebesar 12,78.

\section{b. Pengujian hipotesis II}

Hasil pengujian hipotesis menunjukkan bahwa pengaruh XI pajak terhadap Y menunjukkan nilai koefisien jalur sebesar $(-0,018)$ dengan nilai $\mathrm{T}$ sebesar 0,156 . Dengan membandingkan nilai t $(1,96)$, maka dapat disimpulkan bahwa XI memiliki pengaruh negatif dan tidak signifikansi terhadap Y. Maka hipotesis 2 ditolak.

Menurut penelitian (Amalia, 2020) pengetahuan pajak berpengaruh positif terhadap kepatuhan pajak, sedangkan menurut (Daryatno, 2017) pengetahuan umum perpajakan tidak mempunyai pengaruh terhadap penggunaan e-filing. Dari hasil analisis deskriptif dalam penelitian ini menunjukkan bahwa adanya penyimpangan 1,989 dari nilai mean sebesar 12. Sedangkan dalam penelitian ini pengetahuan perpajakan yang dimiliki oleh responden tidak berpengaruh terhadap minat responden untuk menggunakan sistem e-filing. Diwilayah batas negara RI-RDTL masih adanya 
masyarakat yang belum mengetaui manfaat dari pajak. walaupun pengetahuan tinggi yang dimiliki masyarakat perbatasan RI- RDTL namun pengetahuan perpajakan secara luas tidak ada pengaruh dalam keinginan menggunakan sistem e-filing.

\section{c. Pengujian hipotesis 3}

Hasil pengujian hipotesis menunjukkan bahwa persepsi kemudahan menunjukkan nilai koefisien jalur sebesar 0,815 dengan nilai T sebesar 6,409. dengan membandingkan nilai $\mathrm{t}(1,96)$ maka dapat disimpulkan bahwa X3 berpengaruh positif (signifikan) terhadap Y. Maka hipotesis ketiga diterima

Hal tersebut diatas didukung oleh penelitian yang dilakukan oleh (Kurniawati, 2018) bahwa persepsi kemudahan berpengaruh terhadap keinginan perilaku menggukanan e- filing. Dan menurut (Pu'o et al., 2018) mengatakan persepsi kemudahan memiliki pengaruh positif terhadap keinginan perilaku wajib pajak dalam penggunaan sistem e-filing di Kantor Pelayanan Pajak Pratama Poso.

\section{d. Pengujian hipotesis 4}

Hasil pengujian hipotesis menunjukkan X4 dengan nilai koefisien jalur $(-0,044)$ dengan nilai $\mathrm{T}$ sebesar 0,452 . Dan dengan membandingkan nilai t menurut para ahli $(1,96)$ maka X4 tidak berpengaruh positif (tidak signifikan) terhadap Y. Maka hipotesis 4 ditolak.

Beberapa penelitian terdahulu seperti (Pu'o et al., 2018) mengatakan kesanggupan menggunakan IT memiliki pengaruh positif tehadap keinginan wajib pajak OP dalam menggunakan e-filing. (Wibisono \& Toly, 2014) mengatakan kesiapan teknologi informasi berpengaruh terhadap minat wajib pajak dalam menggunakan sistem e-Filing di Surabaya. Sedangkan yang dikatakan (Daryatno, 2017) mengatakan bahwa kesiapan IT tidak mempunyai pengaruh terhadap penggunaan e-filing.

\section{SIMPULAN}

Tujuan dari penelitian ini guna menganalisis pengaruh sosialisasi pelaporan pajak online, pemahaman pajak, persepsi kemudahan dan persepsi teknologi informasi terhadap minat penggunaan sistem e-filing untuk hotel dan restoran di wilayah 
perbatasan RI-RDTL. Berdasarkan pengujian dan pembahasan, maka dapat disimpulkan bahwa:

a. Hasil pengujian menunjukkan pengaruh positif namun tidak signifikan untuk sosialisasi layanan pelaporan pajak online terhadap minat penggunaan sistem efiling untuk hotel dan restoran diwilayah perbatasan RI-RDTL. Yang artinya responden hotel dan restoran mengetahui bahwa sosialisasi layanan pelaporan pajak online perlu dilakukan untuk memberikan informasi mengenai keefektifan dan efisien dalam menggunakan sistem e-filing kedapa para wajib pajak.

b. Hasil uji hipotesis kedua menunjukkan bahwa tidak adanya pengaruh positif maupun signifikan antara pengetahuan pajak terhadap minat penggunaan sistem e-filing untuk hotel dan restoran diwilayah perbatasan RI-RDTL. Hal ini berarti pengetahuan perpajakan yang tinggi tidak berdampak terhadap keinginan menggunakan sistem e-Filing untuk hotel dan restoran yang berada di wilayah perbatasan RI-RDTL.

c. Hasil pengujian hipotesis ketiga memperlihatkan bahwa XI memiliki pengaruh positif dan signifikan terhadap keinginan penggunaan sistem e- filing di wilayah perbatasan RI-RDTL. Hal ini berarti responden memahami kemudahan dalam penggunaan sistem e-filing.

d. Hasil uji hipotesis keempat menunjukkan tidak adanya pengaruh positif dan signifikan antara pemahaman IT dengan keinginan menggunakan sistem eFiling untuk hotel dan restoran diwilayah perbatasan RI-RDTL. Hal ini menunjukkan bahwa pemahaman teknologi dan informasi yang tinggi tidak berpengaruh terhadap minat penggunaan sistem e-filing.

\section{DAFTAR PUSTAKA}

Amalia, M. (2020). Pengaruh Penerapan E-System, Sosialisasi, Pengetahuan, dan Sanksi Pajak Terhadap Kepatuhan Wajib Pajak Orang Pribadi. Jurnal Ilmu Dan Riset Akuntansi, 9, 24. Retrieved from http://jurnal mahasiswa.stiesia.ac.id/index.php/jira/article/view/2873

Daryatno, A. B. (2017). Faktor-Faktor Yang Mempengaruhi Penggunaan E_Filling Pada Wajib Pajak Orang Pribadi Di Jakarta Barat. Jurnal Muara Ilmu Ekonomi Dan Bisnis, 1(1), 97. https://doi.org/10.24912/jmieb.v1i1.411

Fadhila, \& Diansyah. (2018). Media Studi Ekonomi Volume 21 No . 1 Januari - Juni 2018 Media Studi Ekonomi Volume 21 No . 1 Januari - Juni 2018. Media Studi 
Ekonomi, 21(1), 1-9.

Kurniawati, A. (2018). Analisis Faktor-faktor Minat Perilaku Wajib Pajak untuk Menggunakan E-filing (Studi Empiris di KPP Pratama Sukoharjo). Prosiding Seminar Nasional Mahasiswa Unimus (, 1(2017), 316-322.

Lie, I., \& Sadjiarto, A. (2013). Faktor- Faktor Yang Mempengaruhi Minat Perilaku Wajib Pajak Untuk Menggunakan E-Filing. Tax \& Accounting Review, 3(2), 115.

Nur Anisa Putri, S. T. (2018). Pengaruh Kualitas Sistem Perpajakan Dan Sosialisasi Perpajakan Terhadap Kepuasan Pengguna E-Filing Dengan Kepercayaan Terhadap Otoritas Perpajakan Sebagai Variabel Moderating. Media Studi Ekonomi, 21(1), 1-9.

Pu'o, S., Sondakh, J. J., \& Budiarso, N. S. (2018). Analisis Faktor-Faktor Yang Mempengaruhi Minat Wajib Pajak Orang Pribadi Dalam Menggunakan E-Filing Sebagai Sarana Pelaporan Spt Pada Kpp Pratama Poso. Going Concern : Jurnal Riset Akuntansi, 13(04), 311-324. https://doi.org/10.32400/gc.13.03.20185.2018

Soemitro, H. R. (1992). Pengantar Singkat Hukum Pajak. In Eresco (02 ed., Vol. 02). Jakarta: Eresco.

Wibisono, L. T., \& Toly, A. A. (2014). Analisis Faktor-Faktor Yang Mempengaruhi Minat Wajib Pajak Dalam Penggunaan E-Filing Di Surabaya. Tax \& Accounting Review, 4(1), 1-15. 